\title{
Language Choice and the Construction of Forest Ecology: Lessons from the Mau Forest Restoration Debate in Kenya
}

\author{
Albert Mogambi Moinani, Margaret Nasambu Barasa
}

Department of Languages and Linguistics, Kisii University, Kenya

Received: 11 Oct 2021; Received in revised form: 18 Nov 2021; Accepted: 25 Nov 2021; Available online: 04 Dec 2021 C2021 The Author(s). Published by Infogain Publication. This is an open access article under the CC BY license (https://creativecommons.org/licenses/by/4.0/).

\begin{abstract}
Forest cover in sub-Saharan Africa declined by nearly 10 per cent between 2000 and 2010. Of this loss, 75 per cent was caused by the conversion of forest to human settlement and agriculture largely for food production to serve rapidly growing domestic food demand. Focusing on Kenya, this study examines the political leaders' utterances during the Mau Forest restoration debate in Kenya. Language and environment are closely connected with one another as the existence of a language is influenced by the surrounding natural environment where the language is exploited. Using Critical Discourse Analysis, the study explores the lexical choices of these leaders with a view to establish to what extent their linguistic choices have influenced Mau Forest conservation in Kenya and how local communities have reacted to these dynamics. The findings have indicated a controversial debate for and against forest conservation in Kenya. Some leaders have urged the Kenyan Government to raise public awareness on the dangers of environmental degradation besides taking action against those responsible for environmental degradation whereas others have advocated for human settlement in the forest tower arguing from a humanistic point of view. The findings also indicated that the political leaders' choice of words, lexical items and utterances may not necessarily indicate their political beliefs and attitudes towards environmental Conservation. But because they want to consolidate their political power base and increase political control and support, they use double standard language, and say what people want to hear and in the end the environment continues to be endangered. Therefore, a conclusion is drawn that deforestation is a complex issue whose solutions lie primarily outside the forest itself and that it should be tackled with suitable policies on crucial issues such as land, agriculture, infrastructure and indigenous peoples.
\end{abstract}

Keywords - Lexical choices, Mau Forest, Environmental Conservation, Kenya

\section{INTRODUCTION}

The question of the Mau Forest restoration keeps recurring in the Kenya political scene and is one of the key topics in the current political discourse in the country. The Mau complex is Kenya's largest water tower, spreading over four hundred thousand hectares, thereby making it Kenya's largest chosen canopy ecosystem (Ministry of Environment, 2010; Nema 2008). It is the single most important water catchment in Rift valley and Western Kenya. This is in view of the fact that it is the source of all major rivers that form tributaries from Lake Turkana in the North, to Lake Natron in the south and Kenyans most population Lake Victoria basin (Ministry of environment,
2010). The Mau Forest complex regulates water flow, controls flooding, regulates ground water recharge and most importantly mitigates climate change by storing carbon (Ministry of environment, 2010, Nema, 2008). Therefore, the forest is globally important for mitigating climate change. In spite of its national, regional and global importance, many areas of the forest have been depleted and degraded in the past few decades (Ministry of Environment, 2010). As a result, the Government and its development partners embarked on a programme to rehabilitate the forest (Ministry of Environment. 2010). Despite such efforts, some political leaders from Rift valley come out and campaigned against the forest 
rehabilitation programme. This programme has featured prominently in political campaigns during electioneering periods since 2002 to date. In the meantime, large tracts of the forest have been cleared and turned into farmland (Ministry of environment, 2010). Consequently, several linguists (Lyons, 1985) have conducted numerous studies on the relationship between language and environment. In addition, Muhlhausler (2003:59) asserts that language is born from nature; therefore, the implementation of language studies is always closely related to the environment where the language is used. In this view, this paper highlights how the lexical choices of political leaders have influenced Mau Forest conservation in Kenya and how local communities have reacted to these dynamics.

The world's forests provide valuable contributions to people but continue to be threatened by agricultural expansion and other land uses. According to Geist, Lambin, (2001), deforestation is the outcome of different and simultaneous dynamics where the political system has played a pivotal role. Geist, Lambin, (2001) further observe that all the typical proximate causes of deforestation - namely agriculture, wood extraction and infrastructure - have been at work in the Mau Forest and all these drivers were deeply influenced by political factors. Natural resources are part of the political struggle, being at the same time a means and an end in the relations of powers between the stakeholders (Stefania, Bini, \&Adrien Lindon et Guido Trivellini (2018)). In this regard, Mwenda and Tangri, (2005:449-450) states that the link between natural resources and political issues is crucial in many African States where "politically-mediated access to public resources has been a key mechanism for purchasing allegiance and maintaining support for African rulers". From this perspective, Bratton, van de Walle, (1994) asserts that the control over natural resources becomes a strategic element within the neopatrimonial dynamics that characterize African States.

UNEP 2010 reports indicated that Kenya's forest cover stood at two percent instead of the globally recommended minimum of 10 percent. UNEP and other environment agencies warned that unless this minimum forest cover was attained, the country risked catastrophic ecological disasters. Climate change and global warming are challenges facing the world today. These problems are exacerbated by the fast disappearance of forest cover in the world. Some world leaders have called upon the government to take a stand against climate change and take action against those responsible for environmental degradation because of their boundless thirst for money (The Guardian, 2015). The degradation of the forest is embedded in the desire to make money (Maathai,
2003,2009). This is otherwise referred to as economic opportunism. Economic opportunism is anchored on the belief that human beings should utilize every opportunity available to exploit the resource available in the environment for optimum economic gain. This is also referred to as arithroprocentrism (Alexander \& Stibbe, 2014).

Dealing with environmental issues involves making choices at personal, national or global levels (Kristen and Barbra, 2000). That is, the viewpoint and individual (especially political leader) takes can change the way the public think about environmental issues. Such a view point can fall into any of the following three options: development, conservation or preservation (Kristen \& Barbra, 2000). Development entails exploiting and depleting the environment for economic gains, while conservation entails maintaining the environment the way it is without human interference. In this view therefore, in this paper, we argue that what the political leaders say in regard to forest conservation will either develop, or conserve and preserve the forest. Their voices are very crucial in matters of forest conservation. That is, the lexical choices the political leaders make during their public addresses serve to signal underlying beliefs and attitude towards forest conservation. Political leaders' lexical choices would therefore signal group values and norms and may also inform such groups' actions and decisions. It is therefore, necessary to study political leaders' lexical choices so as to understand their implications for forest conservation.

Degazettement of forest reserves and widespread encroachment has led to the destruction of over one hundred thousand hectares since the year 2000 (Ministry of environment, 2010). The effect of the Mau Forest degradation has been felt in Kenya: shrinking arable land, erratic weather pattern, flooding drought and resurgence of past (Maathai, 2003, 2009: Ministry of environment, 2010). Further, the Government initiated a move in 2010 to evict forest dwellers from the Mau complex so as to allow for rehabilitation of the depleted sections of the forest. Despite these efforts, over two thousand households returned to the forest by 2015. In response, the Government initiated another eviction programme in 2018 , targeting over four thousand households that had encroached on the forest areas again. This move triggered a series of political campaigns against the eviction exercise, with politicians claiming that such a move was meant to oppress their communities for political reasons. It is arguable that these viewpoints could have implications for the public's perceptions about forest conservation. It is on these grounds that this paper sought to analyse the political leaders' utterances and establish to what extent 
their lexical choices have influenced Mau Forest conservation in Kenya and how local communities have reacted to these political discourses. Therefore, the question of who will save the Mau Complex from degradation remains unanswered. Consequently. There is need for studies to complement the efforts of the government environmentalist and other stakeholders in trying to fix the Mau Forest restoration issue so as to avert an environmental disaster.

\section{THE MAU FOREST COMPLEX: SOCIO- ENVIRONMENTAL CONTEXT}

The Mau Forest is the largest nearly-continuous montane indigenous forest in East Africa as well as the most extended natural water tower in Kenya. The forest complex is part of the upper water catchment area of the twelve main rivers of West Kenya that flow into the lakes Victoria, Turkana, Natron, Baringo and Nakuru (Ministry of Environment, 2010). The Kenyan Forest protected areas are divided into National Parks, managed by the Kenya Wildlife Service. The Mau Complex is composed of 22 blocks - all but one of them (the Maasai Mau) declared forest reserves - located along a North-South axis of 150 $\mathrm{km}$ at an altitude of between $1200 \mathrm{~m}$ and $3000 \mathrm{~m}$. The Mau Forest plays an important role in the agricultural, tourism and energy sectors. The climatic conditions of the area adjacent to the forest have supported the development of the cultivation of tea, one of the main national agricultural products. Maasai Mara National Reserve and Lake Nakuru National Park, two famous tourist destinations, take advantage of the rivers that pass through them and that have their sources in the Mau Forest. Finally, Kenya generates more than $44 \%$ of its energy from water and around the Mau Complex several hydro-electric power stations are operational (Ministry of Environment, 2010).

Nowadays, the forest is managed by the State through the Kenyan Forest Service (KFS). The forest was declared a Crown Land in the 1930s, and then gazetted as a Forest Reserve twenty years later. Mau Complex has been subjected to drastic deforestation since the colonial era and especially in the fifteen years before the promulgation of the Forest Act (2005). The region of the Mau Forest was and still is an area inhabited by various ethnic groups. The Ogiek, an indigenous hunter-gatherer group, are considered the historical forest dwellers of Mau (and Mt. Elgon) forests; they are currently estimated around 40,000 individuals in the whole country. Ogiek had strong and frequent relationships with the Maasai and the Kalenjin people, with whom they now share some linguistic traits. The so-called Kalenjin tribe consists of many subgroups (i.e., the Nandi, Tugen, Keyyo, Marakwet, Sabaot, Pokot,
Terik) including the Kipsigis, who are the most numerous in Mau. Finally, the Kikuyu, who arrived in the region because of the British settlers' dispossessions of land, and after independence acquired a relevant political position in the area (Droz, 1998).

\section{POLITICS, ETHNICITY AND FOREST MANAGEMENT}

The Mau Forest tower has been a field of political struggle for so many years. This complex tower represents the ancestral land of the Ogiek tribe (Sang, 2001). Their traditional livelihood was based on wildlife hunting, beekeeping and gathering of food and medicines from the forest, although since 1930s-1940s they started to farm (Kimaiyo Towett, 2004). Until the establishment of the colonial government, the forest land was communally held by several lineages, whose members maintained frequent relationships of exchange and marriage with the neighbouring Maasai and Kipsigis tribes. The arrival of the British settlers was a cornerstone in Ogiek history. They started to be evicted from the forest (1911, 1926, 1932), their land was declared Crown Land (1930s) or allocated to white settlers or other tribes (in Nakuru, Naivasha, Mau Narok); finally, their identity was not recognized, with repeated attempts to assimilate them into the largest ethnic groups, such as Maasai or Kalenjin. First under the colonial rule, later under the independent government, they were marginalized and discriminated against because of their low number and irrelevant political power (Sang, 2001). After three decades of peace, a new phase in the socio-environmental conflict began in 1977. In this year, the national authorities moved against the Ogiek in Tinet (South West Mau Forest), arresting members of the community, destroying their houses and accusing them of being illegal squatters. This course of action, constitutes the background for the forthcoming settlement schemes on excised forest land.

The local community reacted to these initiatives and filed various claims against the government in national and international courts. The last judgement in order of time came out in 2017 from the African Court on Human and Peoples' Rights who recognized the Ogiek as an indigenous population and therein stated that "they [the Ogiek] have the right to occupy their ancestral lands, as well as use and enjoy the said lands" (African Court on Human and Peoples' Rights, 2017, 37). This historical linkage with the forest, together with the presence of a considerable number of Ogiek people in the area surrounding the forest, places this indigenous group in a pivotal position in forest management. The Forest Act (2005) prescribed the development of Participatory Forest 
Management Plans (PFMPs) for each portion of forest through the action of Community Forest Associations (CFAs) (GoK, 2005). Considering that the forest also has a high potential for tourism, new itineraries were developed, members of the Ogiek communities were trained to guide tourists and a new eco-lodge was built in Mariashoni, on the outskirts of the forest. In Koibatek, the CFA was involved in initiatives of reforestation, developing tree nurseries that supply seedlings to the KFS, the County and the schools.

\section{LANGUAGE, POLITICAL DISCOURSE AND ENVIRONMENT}

Kristen and Barbra (2000) argue that there are a number of voices which have revolutionized the world in terms of environmental awareness. These include the voices of John Muir (American writer), Marjory Douglas (American journalist), and Wangari Maathai (Kenyan Biologist and politician). These individuals' speeches and writings on conserving the environment for future generations raised awareness among governments and influenced policies on conserving the environment in different parts of the world. Nature and conservation are a very important part of modern politics. More often than not, connections between language and conservation are hidden and can only be seen by the erudite eye. Most studies on political discourse have focused on the power of the politicians' voices in influencing masses to form opinions and attitudes towards political viewpoints. There is need therefore, to shift focus to other emerging issues such as the politics of climate change and global warming. Linguists should, therefore, use their knowledge and expertise to reveal the hidden connections between language and conservation for social action. In so doing, the linguists will go as long way in educating the people and informing policy makers on the interrelationship between language and forest conservation. This is because of the understanding that political discourse plays a big role in influencing and informing the public's attitude towards forest conservation. Political discourse is a method of decision making (Johnson \& Johnson, 2000). It is about which viewpoints politicians would like their hearers to adopt so as to solve societal issues. This is, political discourse is the formal exchange of reasonable views as to which of several alternative courses of action should be taken to solve societal problems (Johnson \& Johnson, 2000).

Political discourse is concerned with how language can be used to manipulate thought (Leeuwen \& Wodak, 1999). Politicians, more often than not seem to want to hide the negative within particular formulations such that the public may not see truth (Van Dijk, 1998). What a political leader says about the environment can change the way the public view environmental issues (Kristen \& Barbra, 2000, Maathai, 2010). The social impact of language is just powerful. This is because language can be used to lead and mislead and can also be used to distort reality, to hurt others and to shape our perception of the world. Additionally, politicians use language to make their hearers zealots on behalf of the programmes they espouse, consequently making them form opinions favourable to their predetermined ends.

Scholars have interrogated the subject of the environment from different perspectives for instance, from the viewpoint of religion, the issue of environment and its preservation is as old as mankind. According to the bible, after God created Adam and Eve, He put them in the garden of Eden (Genesis 1). God gave Adam the task of naming every plant and animal. Adam was also tasked to lend the garden (Genesis 2). This means that the connection between language and the environment dates back to the beginning of creation. Man was placed at the centre of the environmental conservation course from the time of creation for his own good and that of the other creatures.

The subject of environmental conservation has also caught the attention of linguists, hence the emerging of the sub-discipline of language known as Eco linguistics. This sub-field concerns itself with the interrelationship between language and the environment. Dividing this connection between language and the environment will make the public and policy makers make informed decisions when dealing with environmental conservation issues of the common good of all. The point of most work in ecolinguistics in Kenya is the sustainability of the ecosystem, including human life, especially that of posterity. That is ecolinguistics committed to helping human kind transcend anthropocentrism that marks man's relationship with other species (Alexander \& Stibbe, 2014). Anthropocentrism allows humans to view themselves as the centre of the universe. That is, man is under obligation to do anything in the environment to benefit himself, regardless of the harm it causes other species. Ecolinguistics is thus geared towards relationships which sustain life (Fill \& Muhlhausler 2001; Alexander \& Stibbe, 2014). That us the language speakers use, the type of sentences they construct and the lexical choices they make can be analysed to reveal how they perceive environmental issues (Halliday, 1992; Alexander \& Stibbe, 2014). This implies that language can shape the way humans perceive and construct the physical environment (Fill \& Muhlhausler, 2001). Such perceptions and constructions are revealed through lexicalization. 
Ecolinguistics analyses language to reveal what communities say about the environment and judges these stories according to ecosophy (ecological philosophy). Further, ecolinguistics contributes to be search for new stories about the environment (Stibbe, 2015). This is because ecological but also, moral introspection of anthropocentric activities (Naess, 2008), anthropocentrism is about concern for human at the expense of the other credurs in the environment. That is, as long as humans benefits, there should be no worry about the environment (Stibbe, 2015). However, ecosophy (ecological philosophy) hold that the environment should be protected from man's destructive activities. This is referred to ecocentrism. That is, the environment has a right to live, just like humans. Therefore, man should respect this right and save the environment from destruction (Alexander \& Stibbe, 2015). The field of environment conservation requires collaborative effort of experts from diverse fields (Vaccaro \& Beltran, 2013). It is our informed view that linguists should also claim their position in responding to the environmental problems facing the world today for the common good of all. The mentality that environmentalism is anti-development needs to be changed (Maathai, 2009, 2010). Kenyan forests have fallen victims to deforestation activities disguised as development by cartels linked to milking and charcoal making. (Maathai, 2009). Despite manifestation such as rising temptations, flooding and drying rivers, political leaders and stakeholders the milling and charcoal business continues to deny the fact that human activities are linked to the degradation of forests (Maathai, 2009) by so doing, Kenyans are slowly killing themselves (Maathai, 2003) because of the love of money. The fact that Kenya is a signatory to many of the intentional climate change conventions and has presentation in global climate change conferences indicates that the government knows what to do in terms of environmental conservation (Maathai, 2009).

\section{METHODOLOGY}

This study takes a qualitative approach in the analysis of political discourse on the Mau Forest conservation issue. This study focuses on the description and critical analysis of the political leaders' language use during the 2010-2014 Mau Forest restoration debate. This study interrogates the political leaders' choice of words, language features, and implications for Forest conservation in the country. Above all, this study critically analyses how the political leaders linguistically defined and constructed Forest conservation, the attitudes, and ideologies underpinning the political discourse on the Mau Forest conservation. A total of ten (10) speeches were sampled for analysis. The speeches were accessed from the live political meetings, internet and the YouTube. These included speeches by political party leaders, presidential candidates, and members of parliament made during the 2010-2014 Mau Forest restoration debate. The audiorecorded speeches were transcribed, translated into English where appropriate, coded and analysed using the Critical Discourse analysis framework. This was done with a view to tease out the lexical items which bring out the voices, the attitudes and the feelings of both the speakers and the community. Some sample speeches were also recorded and aired by media houses during prime-time news. The data analysis, explanation and interpretation was guided by Norman Fairclough's and Ruth Wolak's (1997) Critical Discourse Analysis (CDA) framework. CDA therefore helped the researchers in tracing the underlying attitudes from the lexical choices manifest in political discourse on forest conservation. CDA also helped in the analysis of the connotations of the words and phrases the political leaders used during the forest conservation debate. Connotation often carries an evaluative element, making it negative or positive. The use of particular words and phrases within the context of Mau Forest restoration debate would imbue these items with hidden meanings which would in turn provide cultural and ideological information. Data was presented as transcripts or excerpts of political utterances.

\section{LEXICAL CHOICES AND FOREST CONSERVATION}

The lexical choices political leaders made during the Mau Forest restoration debate serve to indicate their support for forest exploitation for economic gain, regardless of the harm caused on the environment. The following examples illustrate this.

\section{Example 1}

I have retired but that doesn't mean that I shut up! An outsider or even leaders from outside come to dictate what people of the Rift Valley should do-Are there no men and leaders in the Rift Valley? Members of parliament are not the only leaders. It is mandatory to consult the people even on the Mau issue. Can't you sit and deliberate on how people will be moved out of the forest, where they will be resettled! You push people in the name of the water catchment areasand you shout eviction! Eviction! You xxxx you push people, are people rats and cats? 
Forests are burning all over. Trees. are being felled like xxx and they keep on shouting Mau! Mau! Mau!

Example 1 above implies that the speaker prefers economic exploitation to forest conservation. That is, the speaker acknowledges that the Mau Forest is being degraded at a very high rate but insists that there must be consensus on how those occupying the forest areas could be moved and resettled elsewhere. The speaker's assertions: 'Forests are burning all over' and 'Trees are being felled' are indicative of the rapid degradation of the forest due to human activities. In this way, instead of calling for the speedy eviction of settlers from the forest, the speaker expresses his opposition to the forest conservation programme, an act of economic opportunism. In this context, using the us/them strategy (Van Dijk, 1998), the speaker in example 1 above accuses those calling for the eviction of people from the Mau Forest of meddling with the affairs of the locals: 'An outsider or even leaders from outside come to dictate what people of the Rift Valley should do-Are there no men and leaders in the Rift Valley?'.

In this case, by referring to his opponents as outsiders or leaders from outside, the speaker depicts them as not being entitled to make policies regarding the conservation of the forest that falls within the Rift Valley region. The speaker insisted that the forest settlers had to be given alternative settlement first before being told to move out of the forest. For him, being given more time meant more destruction of the Mau Forest. By allowing settlers to continue staying in the forest, however, meant more destruction to the forest, hence, the speaker's implied support for the continued occupation of the Mau Forest by settlers for material gain. Similar sentiments are expressed in example 2 below.

\section{Example 2}

We are not opposing anyone and if there is someone who is opposed to the protection of the Mau Forest, that person must be insane. We agreed that those in the Mau Forest-should be resettled elsewhere- and those with title deeds should be compensated before they leave to pave way for the planting of trees in the forest. We do not deny it- charcoal burning and felling of trees is going on... Because forests are important, human life is equally important. Those citizens in the Mau Forest have not refused to relocate. They can only move out after being shown where they will be relocated to and resettled.
But telling us that a deadline has been set for the people to be evicted by force-we will never let it happen.

Example 2 suggests that economic exploitation blamed for forest destruction, is ongoing in the Mau Forest. The speaker in the extract above acknowledges that felling of trees and making of charcoal are still rampant in the Mau Forest: 'We do not deny it-charcoal burning and felling of trees is going on', hence, the settlers' role in promoting economic/material exploitation of the Mau Forest. Although the speaker above says that they (he and his supporters) are not opposed to the conservation of the Mau Forest, his insistence on the forest settlers being compensated before moving out of the Mau Forest proves otherwise. The speaker further states that he will never let the government evict the settlers before being compensated: 'But telling us that a deadline has been set for the people to be evicted forcefully-we will never let it happen'. This is an act of double- speak (Achieng, 2007).

That is, the speaker appears to be supporting the need to conserve the Mau Forest but at the same time opposes the eviction of the Mau settlers before they are compensated. As such, the speaker also emphasizes the issue of compensation and resettlement of the Mau settlers despite the ongoing destruction of the Mau Forest. This shows that material gain is prioritized over forest conservation. The speaker above further says that he will oppose the eviction of the people until they are compensated or given alternative settlement. According to the speaker, human settlement is more important than forest conservation. Sample 3 further indicates resistance to forest eviction.

\section{Example 3}

On the Mau issue, we warn our members of parliament not to betray our people. What is important as far as Mau Forest is concerned is for our people to be compensated!

If forests are important-then human life is equally more important. Those Kenyans in the Mau Forest have not refused to leave.

But they will only leave when they will be shown where they will resettle and rebuild their homes.

Example 3 indicates the speakers' emphasis on compensation instead of conservation. The speakers insist that their people (ethnic members) will only leave the forest after being compensated or resettled elsewhere: They will only leave when they will be shown where they will resettle and rebuild their homes'. Their insistence on 
compensation implies that they are in favour of economic exploitation of the forest. That is, as long as the people have not been compensated, they will continue to occupy the forest, hence its continued degradation.

The speakers in example 3 above use words with positive connotations to refer to the people in the forest. The use of the words 'Kenyans', 'citizens' and 'our people' above serve to portray the people in the Mau Forest positively. The speaker identifies himself with this group by invoking 'our people'; thereby suggesting that he shares the same values and beliefs with this group. The use of the term 'our people' is meant to make the Mau settlers feel good and cared for by the speaker, thus promoting his ability to gain public support and following. This understanding coheres with Achieng' (2007) who holds that political discourse is characterized by double-speak. That is, the speakers mentioned above are aware of the dangers of forest occupation but openly declare their opposition to the eviction of settlers from the forest. This is, most likely, due to the fact that they stand to lose the grassroots political support of the masses, who are mostly the victims of forest evictions.

As a consequence, the forest conservation programme is sacrificed at the altar of political gain. The use of words such as 'compensate', 'resettle' and 'relocate 'in the excerpts above are indicative of the speakers' preference for the economic exploitation of forests, as opposed to their conservation. The use of 'we' together with expressions such as 'will never let it happen' and 'not to betray our people 'above suggests that taking economic advantage of the Mau Forest supersedes forest conservation. This said otherwise entails playing politics with the Mau Forest issue, despite the danger that the ongoing human activities in the forest pose to the natives of the Rift Valley and others downstream. In this case, the speakers may be opposed to the conservation of the Mau Forest, because this is the general stance being held by the political leaders of the Rift Valley region as illustrated in the use of the pronoun, We. This observation agrees with Masime and Oesterdiekhofff (2010) that most politicians follow their political leaders' positions on salient national issues.

This means that the aforesaid leaders could be expressing their opposition to the forest conservation programme probably to sound politically correct. It is also important to note that the speakers in the samples above ignore to mention all those responsible for the felling of trees and making of charcoal. That is, they acknowledge that there is rampant felling of trees in the Mau Forest coupled with large scale charcoal burning, yet they seem reluctant to name those responsible for the same.
The speakers in the sample extracts, therefore, use passive constructions, which makes it possible for them to avoid mentioning those felling trees and burning charcoal in the Mau Forest: 'charcoal burning and felling of trees is going on' and 'forests are burning everywhere...all over.... trees are being felled like... We do not deny itcharcoal burning and felling of trees is going on'. Although the speakers are aware that the people occupying the forest are causing damage, they avoid mentioning them. This is most likely informed by the politicians' awareness that the Mau settlers do not want to leave the forest, hence their careful use of language, so as to please the public and consequently gain political mileage.

From the perspective of Halliday's (1985, 1994) concept of SFG that sees language as a system that serves different functions, the use of passive sentences above indicates the speaker's non-committal stance towards the forest conservation issue. The passive sentences used above (charcoal burning and felling of trees is going on' and 'forests are burning everywhere... all over.... trees are being felled like... We do not deny it-charcoal burning and felling of trees is going on) omit the subjects responsible for the burning of the forest and felling of trees. This implies that the speakers are consciously avoiding to mention those responsible for the destruction of the Mau Forest.

According to Halliday (1994), what an individual feels based on his experiences of the world is reflected in the kind of sentences he/she constructs as well as what his/her choice of words foregrounds or backgrounds. The use of agentless sentences (passive) highlighted above implies the speaker's stance towards the subject. By avoiding to mention those responsible for the destruction of the forest, the speakers above show that forest conservation is not of prominence to them. The use of the pronoun we also signals the political leaders' position that conservation of forests is not a priority to them as a community (the use of we/our people is illustrative of this voice), and that what is key is compensation (economic exploitation). Their insistence on compensation before the settlers move out of the forest is indicative of their privileging of economic opportunism at the expense of conservation.

In other words, the felling of trees and burning of charcoal will go on until their people are compensated or relocated: We do not deny it- charcoal burning and felling of trees is going on'. These views are in tandem with the sentiments of Pope Francis, the Catholic Church leader and former US President, that there is urgent need to take action against those responsible for environmental degradation because of selfish and boundless thirst for 
money. The leaders stressed that unless governments and world leaders take a stand against climate change, these individuals will destroy the earth through environmental degradation. Sample 4 below is illustrative of the view that exploitation of the forest for economic gain is preferred more than conservation of the same forest.

\section{Example 4}

I will also take care and observe forest conservation procedures-But when trees compete with a child, a mother- an old woman- my priorities are very right on that one! I will have to take care of the human being first; child, mother and then I can take care of my trees.

Example 4 indicates the speaker's stance towards forest conservation. The speaker, thus, asserts that when faced with conflicting interests between forest conservation and economic exploitation, he will prioritize the latter over the former (when trees compete with a child, a mother-an old woman- my priorities are very right on that one! I will have to take care of the human being first). Mother, child and old woman fall into the marginalized groups which need protection. This is what Kristen \& Barbra (2000) call the making of choices in as far as dealing with environmental issues is concerned. What is more, the making of choices can be at personal, national or global level. The speaker in the example above makes a personal choice; by choosing development and not conservation. Notice, however, that the choices an individual makes can change the way people think about environmental issues. The speaker's use of the possessive form (singular personal pronoun) 'my' implies that he views the forest as a personal property and not a common heritage of the people of Kenya: 'I will have to take care of the human being first; child, mother and then I can take care of my trees'.

Therefore, from the perspective of Fairclough's (1995) concept of hegemony, he has the power and authority to choose what he feels to be right at any given time, in regard to the forest. Notice however, that allowing people to continue occupying the forest will lead to further degradation of the forest. This viewpoint can influence the way others think about the Mau Forest conservation issue, hence accepting the speaker's view that the economic exploitation of the forest is more important than conservation. The following sample 6 further illustrates the act of how politicians' double-speak and are dishonest.

\section{Example 5}

The politicians in the Rift Valley, who obviously whose communities are the ones greatly benefited from this part of the Mau - are the ones who are putting-pushing the government to compensate because they want their people to be compensated. But I want to remind us that in Enosupukia, Kikuyus were evacuated by force and we remember people even died.

And I remember president Kibaki when he went to see-these displaced people in Maela. Nobody said these people should be compensated!

Everybody said nobody should be sitting -on a watershed area. And I remember that Minister Ntimama was extremely vocal-about these people needing to be evacuated.

So, I think we are not genuine, we are not honest. I am not defending - much-whoever allocated the people in Enosupukia, but surely, if we removed people from Enosupukia in the name of protecting the watershed area, shouldn't we remove people from the other side of the forest in the name of protecting the same forested area?

Because as the population increases, the situation will only get worse- if we do not reverse the destruction processes- that we've been engaged in. if we destroy nature, nature will destroy us. Please, let's preserve our forests.

Some individuals are saying that our people cannot leave before they are compensated. Our people - but aren't all the citizens of Kenya your people?

The speaker in example 5 above laments the degradation of the Mau Forest. He/she argues that the political leaders, who are natives of the Rift Valley, are protecting members of their ethnic communities: 'are the ones who are putting-pushing the government to compensate because they want their people to be compensated'. The speaker asserts that the politicians are concerned with compensation more than conservation. The speaker, however, acknowledges that the people of Rift Valley have been engaged in destructive practices in the Mau Forest, yet the political leaders are protecting them by insisting that Mau settlers could not leave the forest before they are compensated. The leaders, therefore, prefer monetary gains to environmental conservation. This, in the researchers' view, is ill informed because the leaders will not protect the people when nature strikes back: 'if we destroy nature, nature will destroy us. Example 5 also 
indicates the politicians' double-speak: 'if we removed people from Enosupukia in the name of protecting the watershed area, shouldn't we remove people from the other side of the forest in the name of protecting the same forested area?'. The speaker here claims that the same politicians, defending those in the Mau Forest were the same ones that urged the government to evict members of other communities from the forest. The aforesaid politicians, therefore, want members of their ethnic community to benefit fully from the forest, in spite of the dangers the human activities are most likely going to cause.

\section{Example 6}

On the Mau issue, I will publicly announce the names of all those who own land in the forest so that the citizens get to know them. I have obtained a list from the ministry of lands of all those who were fraudulently allocated land in the Mau Forest. These individuals own many hectaressome one thousand, others two thousand and even five thousand hectares in the Mau Forest. For those who bought land from fraudsters who had encroached on the Mau Forest, we will find a way of resettling them elsewhere

Example 6 implies that the Mau Forest occupation is regarded as a money-making enterprise. The speaker in the extract above asserts that there are individuals who own thousands of hectares of land in the Mau Forest: 'These individuals own many hectares- some one thousand, others two thousand and even five thousand hectares in the Mau Forest', thereby suggesting that the people prefer economic exploitation to forest conservation. The revelation that he had obtained a list of the people allocated land in the forest from the Ministry of Lands (government) implies that the policy makers themselves prefer economic exploitation to forest conservation. It is ironical, however, that the people who are supposed to protect the forest are the ones being accused of allocating individuals land in the forest area that ought to be conserved.

Notably, the speaker's claim above that the Ministry of Lands was in possession of a list of those that had encroached onto the Mau Forest indicates that economic exploitation of the Mau Forest is given preference over its conservation. These assertions agree with the head of Catholic Church, Pope Francis's claim that there are individuals who are out to destroy the environment due to their selfish and boundless desire for money. The Pope thus, called for governments and world leaders to stop these individuals before they completely destroy the earth through environmental degradation.

Giving economic exploitation preference is dangerous, because what politicians say sets the agenda for discussions among the public (Ralph \& Stanyer, 2007). That is, these discussions or public debates on forest conservation go a long way in shaping people's opinions on different issues, forest conservation included. Political leaders are part of the elites who control public discourses (Fairclough 2001), besides playing a role in the reproduction of dominant knowledge and ideologies in the society (Van Dijk, 2000). The public discourse of the elites (e.g., politicians, teachers, journalists) is, therefore, the primary source of shared ethnic prejudices and ideologies (Van Dijk, 1993). Therefore, the politicians' ideology of economic exploitation of the Mau Forest will characterize the people of Rift Valley's perceptions of the Mau Forest conservation programme.

\section{CONCLUSION}

Political discourse uses language to conceal the harm human activities cause on the environment. Political leaders choose specific words that covertly indicate they prefer forest exploitation for economic gain to conservation. The political leaders seem to care more about economic gain for themselves and their supporters (ethnic communities) in total disregard of the harm human activities cause on the environment and attendant consequences. There is need for linguists to use their expertise in languages to enable the public to see the horrors of environmental degradation common fledged as development. The public will thus make informed decision and take appropriate action feared towards saving the Mau Forest for posterity.

The findings indicated that the Political leaders' choice of words, lexical items and utterances may not necessarily indicate their political beliefs and attitudes towards environmental Conservation. But because they want to consolidate their political power base and increase political control and support, they use double standard language, and say what people want to hear and in the end the environment continuous to be endangered. The reasoning is that during such an electioneering period (2010-2014) most political leaders do not really mean what they say. The motive behind their utterances and choice of words is mostly to get more votes and to consolidate political support from the locals. Hence, they disregard environmental conservation and endanger the Mau Forest in order to achieve their political interests. On the other hand, in as much as most leaders' utterances were against the Mau Forest conservation, there were some whose 
choice of words supported forest conservation. The processes analyzed show the importance of the political dimension in deforestation and forest degradation processes: the government has played a pivotal role in the three sectors and the forest has been used as a strategic asset in the political struggle on a national scale.

The political leaders' lexical choices indicate that the political class prefers forest exploitation for economic gain to forest conservation. The political leaders perceive the Mau Forest as a resource for their followers to use to enrich themselves, despite the harm this causes the environment. Although development is desirable and money is good, destroying forests in the name of making money is courting disaster. This is because nature, though generous, is unforgiving once destroyed.

\section{REFERENCES}

[1] Achieng', B. (2007) Interpretations and Implications of political discourse: A Kenyan experience. Unpublished M.A thesis Egerton University.

[2] Alexander. \& Stibbe, A. (2014). 'From the analysis of ecological discourse to the ecological analysis of discourse'. Language science 41.104-110.

[3] Barasa, N. M. (2014). Discursive strategies in Kenya's 2008 post-election consultation discourse. Unpublished $\mathrm{PhD}$ Thesis: Laikipia University.

[4] BRATTON M., VAN DE WALlE N. (1994), "Neopatrimonial Regimes and Political Transitions in Africa", World Politics, 46, 4, Cambridge University Press, pp. 453-489.

[5] DROZ Y. (1998), "Genèse d'une "ethnie": le cas des Kikuyus du Kenya central », Canadian Journal of African Studies, 32, 2, pp. 261-284.

[6] GOVERNMENT OF KENYA (GoK), UNEP (2008), Mau complex and Marmanet forests, environmental and economic contributions, Briefings notes, UNEP.

[7] GOVERNMENT OF KENYA (GoK), MINISTRY OF FORESTRY AND WILDLIFE (2013), Analysis of drivers and underlying causes of forest cover change in the various forest types of Kenya, Nairobi, GoK.

[8] Fairclough, N (2001). Language and power. London: Pearson Education.

[9] Fairclough, N, \& Wodak (1997). Critical discourse analysis: The critical study of language. London: Wesley publishing Co.

[10] Fairclough, N, (1995). Critical discourse analysis; the critical study of language. New York.

[11] Fill, A. \& Muhlhausler, P. (2001). The ecolinguistics reader: language, ecology and environment. New York: Continuum.

[12] Geist, H. J., \& Lambin, E. F. (2001). What drives tropical deforestation. LUCC Report series, 4, 116.

[13] Halliday, M.A.K. (1992). 'New ways of meaning: the challenges to applied linguistics', in Putz, Matin (ed): Thirty years of linguistic evolution. Amsterdam: John Benjamins Co.

[14] Johnson, D. \& Johnson, R. (2000). Civil political discourse in a democracy: the contribution of psychology. University of Minnesota. 60 Park Hill.

[15] Kristen, E. B \& Barbra (2000). Science Explorer. New Jersey: New Hall.

[16] KIMAIYO TOWETT J. (2004), Ogiek Land Cases and Historical Injustices 1902-2004, Egerton, Nakuru, Ogiek Welfare Council.

[17] Van Leeuwen, T., \& Wodak, R. (1999). Legitimizing immigration control: A discourse-historical analysis. Discourse studies, 1(1), 83-118.

[18] Lyons J 1995 Introduction to Theoretical Linguistics. Cambridge: Cambridge University Press. P. 7

[19] Maathai, W.M. (2009). The Challenge for Africa: A new vision.

[20] Maathai W.M. (2003). The Green Belt Movement: sharing the Approach and experience. New York. Lantern.

[21] Maathai, W.M (2009). The Challenge for Africa. New York: Anchor.

[22] Maathai W. M (2010). Representing the Earth: spiritual values for healing ourselves and the world. New York. Doubleday Image.

[23] Masime, K. \& Oesterdiekhoff, P. (2010). Institutionalizing political parties in Kenya: Centre for Governance and Development: Friedrich Ebert Stiftung.

[24] Mau Forest speeches. Retrieved from https://www.youtube/watch

[25] Muhlhausler P 2003 Language of EnvironmentEnvironment of Language. A Course in Ecolinguistics, London: Battlebridge.p.59

[26] Ministry of Environment (2010). National climate change response strategy. Nairobi: GOK printer.

[27] Mwenda A.M., Tangri R. (2005), "Patronage Politics, Donor Reforms, and Regime Consolidation in Uganda", African Affairs, 104, 416, Oxford University Press, pp. 449-467.

[28] Naess, A. (2008). Ecology of wisdom. Berkley, C.A: Counterprint.

[29] NEMA (2008). State of Environment Report Kenya, 2006/2007: Effects of climate change and coping mechanisms in Kenya. Nairobi: NEMA.

[30] Ralph N. and Stanyer, J. (2007). The politician communication reader. New York: Routledge.

[31] SANG J.K. (2001), "Kenya. The Ogiek in Mau Forest", in NELSON J., HOSSCAK L. (eds.), From Principle to Practice: Indigenous Peoples and Protected Areas in Africa, Forest Peoples Project, pp. 111-194.

[32] Stefania Albertazzi, Valerio Bini, Adrien Lindon et Guido Trivellini (2018). Relations of power driving tropical deforestation: a case study from the Mau Forest (Kenya). Bulgian Journal of Geography /.https://doi.org/10.4000/belgeo.24223

[33] Stibbe, A. (2014). An ecolinguistics approach to critical discourse studies. Critical discourse studies 11(1) 117-128.

[34] The Guardian (2015, September 25). US Catholics ready to follow Pope's marching orders on climate change: https:// www.guardian.com 
[35] The White house office of the press secretary (2015, September 28). Remarks by President Obama to the United Nations General Assembly. New York: https:// Obama Whitehouse archives.gov

[36] United Nations Environmental Programme Vaccaro, I. \& Beltran, O. (2013). Political ecology and conservation policies: some theoretical genealogies. Pierre Alexandre Paquet.

[37] Van Dijk, T. (2000). Critical discourse analysis. (http://www.discourse-in-society.org/).

[38] Van Dijk, T. (1998). Ideology. A multidisciplinary study. London: Sage.

[39] Van Dijk, T. (1993). Principles of critical discourse analysis. discourse and society 4'. 